https://doi.org/10.17048/AM.2020.342

\title{
Komló Csaba
}

Eszterházy Károly Egyetem, Digitális Technológia Intézet, Digitális Kultúra Tanszék

komlo.csaba@uni-eszterhazy.hu

\section{D eszközök az oktatásban}

\section{Absztrakt}

Ahogyan életünk egyre több színterén, így az oktatásban is kiemelten fontos szerepet játszanak a digitális eszközök. Ezek az eszközök életünket gyakran könnyebbé, tevékenységeinket hatékonyabbá teszik, az oktatásban pedig - többek között - ezektől az eszközöktől várjuk az élményszerúség megvalósítását. A minket körülvevő, az adatok, információk, ingerek millióit ránk szabadító virtuális környezet egyik hátránya, hogy a gyerekek hozzászoknak a mindig új, mindig érdekes, vizuálisan vonzó formában megjelenő tartalmakhoz, és erre az oktatásnak is reagálnia kell. A reakció egyik iránya, hogy olyan technikai eszközöket és módszertani megoldásokat integrálunk az oktatási folyamatba, amelyek képesek megragadni és fenntartani a tanulók érdeklődését. Míg a kilencvenes években a multimédia, később az internet, a web 2.0, a közösségi háló majd a mobil applikációk töltötték be ezt a szerepet, addig mára a 3D eszközök kerültek a figyelem középpontjába.

Kulcsszavak: virtuális valóság, 3D nyomtatás

\section{Bevezetés}

Napjainkban már az oktatásban is kiemelten fontos szerepet játszanak a digitális eszközök. Ezek az eszközök életünket gyakran könnyebbé, tevékenységeinket hatékonyabbá teszik, az oktatásban pedig - többek között - ezektől az eszközöktől várjuk az élményszerűség megvalósítását. A minket körülvevő, az adatok, információk, ingerek millióit ránk szabadító virtuális környezet egyik hátránya, hogy a gyerekek hozzászoknak a mindig új, mindig érdekes, vizuálisan vonzó formában megjelenő tartalmakhoz, és erre az oktatásnak is reagálnia kell. A reakció egyik iránya, hogy olyan technikai eszközöket és módszertani megoldásokat integrálunk az oktatási folyamatba, amelyek képesek megragadni és fenntartani a tanulók érdeklődését. Míg a kilencvenes években a multimédia, később az internet, a web 2.0, a közösségi háló majd a mobil applikációk töltötték be ezt a szerepet, addig mára a 3D eszközök kerültek a figyelem középpontjába. 
Amikor 3D eszközökről beszélünk, gondolatban mindig hozzátesszük, hogy digitális technológiához köthető eszközökről van szó, hiszen 3D eszköz volt pl. gyermekkorom kedvenc számolóeszköze, a színesrúd készlet is, ami valószínúleg nem hozná lázba a mai diákokat. Számos kutatás (Bamford, 2011, Shibata, 2014, Shibata 2017) támasztja alá, hogy a 3D környezet pozitív fogadtatásra talál és stimulálólag hat a tanulókra.

\section{A virtuális valóság}

A digitális technológia segítségével létrehozott 3D terek egyik legizgalmasabb változata a virtuális valóság. Nem meglepő, hogy a virtuális kifejezés is elsőként a virtuális valósággal vált ismertté, majd egyre szélesebb körben terjedt el a használata. Ennek a munkának a keretei nem teszik lehetővé, hogy a valóság ontológiai vagy episztemiológiai vizsgálatára kitérjünk, ezért a virtuális valóság kapcsán elsősorban a virtualitás fogalmára koncentrálunk, amelynek jelentését megvizsgálva három választ kapunk (a Magyar Nyelv Értelmező Szótára szerint):

- Látszólagos, nem valódi

- Lehetőségként élő, lappangó

- Várható, a jövőben lehetséges

A virtuális valóság kifejezést, pontosabban annak angol megfelelőjét (Virtual Reality) Jaron Lanier használta először. A „virtuális” kifejezés gyakran arra utal, hogy az adott, fizikailag létező tárgy számítógéppel előállított másolatáról van szó: „virtuális szoba”, „virtuális kesztyü”, „virtuális szék”, "virtuális környezet". Tágabb értelemben a virtuális világ kifejezés magába foglalja a digitális technológiával létrehozott entitásokat is, pl. közösségi háló, számítógépes játékok, mobil applikációk stb., de a következő néhány oldalon elsősorban a szúken értelmezett virtuális valóságról lesz szó.

A téma viszonylagos újszerűségéből adódik, hogy a virtuális valóságnak (röviden: VV) sincs egyetemes definíciója. Ráadásul a virtuális valóság elnevezést sokféle jelenségre használják, illetve a virtuális valósághoz kapcsolódó fogalmaknak más elnevezései is voltak korábban: mesterséges valóság, számítógéppel létrehozott mesterséges környezet stb., de ezek közül mára a virtuális valóság vált a legelterjedtebbé. A szűken értelmezett virtuális valóság úgy is definiálható, mint számítógéppel vezérelt multiszenzoros kommunikációtechnológia, amely lehetővé teszi az intuitív interakciót az adatokkal, objektumokkal, valós vagy virtuális személyekkel. A VV képes létrehozni az immerzivitás érzését, azaz a perceptuális és pszichológiai érzetét annak, hogy a digitális világban vagyunk, ahogyan a szó eredeti jelentése utal rá: "belemerülünk" a digitálisan megalkotott világba. Az immerzivitás érzése nagyon fontos az élmény minőségének szempontjából, ehhez azonban olyan szoftver- és hardverkörnyezet kell, amely csak az utóbbi néhány évben vált széles körben elérhetővé. A virtuális valóság tipizálásánál - különösképpen az ezredforduló előtti múvekben - megjelennek olyan elemek is, amelyek 
nem, vagy csak részben képesek az immerzivitás élményét megadni a felhasználónak. Az immerzivitás élménye annyira fontos, hogy Sherman és Craig (2002) szerint ez az egyik legfontosabb a VV 4 kulcseleme közül (a másik három: a digitálisan létrehozott virtuális világ vizuális minősége, az interakció a felhasználó és a virtuális világ elemei között és a szenzorokra épülő visszacsatolás a felhasználó mozdulatairól és pozíciójáról).

\subsection{A virtuális valóság típusai}

A tipizáláshoz felhasználásra került többek között McLellan (1997) rendszerezése, amely jó alapot ad a kategóriák felállításához, azonban az azóta eltelt több mint 20 év miatt számos esetben szükségessé vált az akkor leírtak kiegészítése, átdolgozása.

\subsubsection{Immerziv, egyes szám első személyű virtuális valóság}

Amikor virtuális valóságról beszélünk, többnyire azokra az immerzív rendszerekre gondolunk, amelyek legfontosabb jellemzője a számítógéppel létrehozott háromdimenziós tér, és amelyben a felhasználó a VV sajátos hardver eszközeit is használja: pl. fejre erősíthető megjelenítő (sisak), a virtuális térben való interakciót segítő kesztyűk, pozíciókövető eszközök és térhatású hangrendszer. Az egyes szám első személyú elnevezés onnan ered, hogy a felhasználó a saját szemszögéből látja a digitálisan létrehozott valóságot.

\subsubsection{Kiegészített valóság (Augmented Reality)}

A kiegészített valóságot az 1990-es évek végén az immerzív, egyes szám első személyű virtuális valóság egyik típusának tartották (McLellan (1997)). Véleményem szerint ez az álláspont ma már vitatható, a valóság - kiegészített valóság - virtuális valóság egyfajta fokozatosságot is jelöl, hogyan csökken a valós elemek, és növekszik a számítógéppel létrehozott objektumok száma a valóságtól a virtuális valóság felé haladva.

Isdale (2001) szerint a kiegészített valóság egy számítógépes grafikával létrehozott átlátszó réteg, amelynek az a feladata, hogy kiemelje a valóság bizonyos elemeit, illetve segítse a tájékozódást vagy megértést. Ebben az időben szinte csak a katonai célú felhasználása volt ennek a technológiának (pl. vadászpilóták sisakjába építve), azonban a Google által 2013-ban kifejlesztett Google Glass széleskörűen elérhetővé tette ezt a rendszert.

A kiegészített valósághoz köthető alkalmazások a tabletek és mobiltelefonok megjelenésével váltak széles körben elérhetővé. Ennek az az oka, hogy a kiegészített valóság (KV) egyik leggyakrabban használt típusa úgy múködik, hogy ún. markereket helyeznek el egy felületen (pl. prospektus, tankönyv stb.). A telefonon vagy tableten futó alkalmazás megjeleníti a kamera képét az eszközön, fel- 
ismeri a markereket, majd a kijelzőn és az alkalmazásban beprogramozott módon kiegészíti a valóság megjelenített képét.

A markerek lehetnek hagyományos QR kódok, de olyan vizuális elemek is, amelyet jóformán észre sem veszünk. Természetesen nem csak markerek indikálhatják a valóság kiegészítését, hanem pl. GPS koordináták is, de arra is van lehetőség, hogy a kiegészítő elem folyamatosan a képernyőn legyen (pl. kipróbálhatjuk, hogyan nézne ki az új kanapé a nappalinkban).

\subsubsection{Ablakon keresztül megtekintett virtuális valóság}

Ebben a rendszerben, amelyet az asztali számítógépek virtuális valóságának is neveznek, a monitoron keresztül tekinthetünk be a virtuális háromdimenziós világba, és a számítógépek hagyományos eszközeivel navigálhatunk (pl. egér). Az élmény természetesen elmarad az immerzív VV-tól, de ez a megoldás igényli a legkisebb anyagi ráfordítást és egyszerre többen is megtekinthetik.

\subsubsection{Tükrözött világ}

Az egyes szám első személyú virtuális világokkal szemben a tükrözött világ (vagy kivetített valóság) második személyű megtapasztalást tesz lehetővé, ahol a néző a képzeletbeli világon kívül áll, de kommunikálni képes a kivetített világ személyeivel vagy objektumaival. A tükrözött világ fontos eleme a számítógéppel összekötött kamera, amely a néző alakját egyesíti a háttérrel és egy nagyméretú monitoron vagy egy kivetítőn jeleníti meg.

\subsubsection{Virtuális animáció (virtuális személyek, Waldo World)}

Ez a fajta virtuális valóság a digitális bábozás és a real-time számítógépes animáció keveréke. A Waldo World elnevezés Robert Heinlein Sci-Fi történetéből származik a hatvanas évek közepéről.

Az eljárás során a mozgást az arcra és/vagy a testre felszerelt szenzorokkal rögzítik és ezen az információn alapszik a digitális karakter mozgatása. A virtuális animáció továbbfejlesztett változata a motion capture vagy mocap eljárás, amit ma is használnak (pl. https://www.vicon.com/aboutus/what-is-motion-capture/)

\subsubsection{Virtual Cave (virtuális barlang)}

A barlangvilág egy viszonylag kis méretú, vetített virtuális valóság környezet, amely rendszerint egy olyan kockára hasonlít, amelynek az egyik oldala nyitott. A kocka fala áttetsző anyagból készül és a kocka belsejében a falakra vetített kép hozza létre az immerzív élményt. A felhasználóknak a látvány megtekintéséhez speciális szemüveget kell viselniük és egyszerre csak egy felhasználó léphet interakcióba a barlang objektumaival. 


\subsubsection{Autószimulátor környezet}

Az egyes szám első személyű virtuális valóság technológia egy másik típusa, amely egy hagyományos szimulátor továbbfejlesztése. Ebben az esetben is több projektor állítja elő a képi információt és gyakran valódi jármúvet használnak, amelynek a kezelőszerveit és a műszerfalat szimuláló monitort összekötik a számítógépekkel. A felhasználó szempontjából az autószimulátor környezet immerzív, hiszen a kocsiban ülve a szélvédőn kitekintve és a visszapillantó tükrökben is csak a számítógépekkel létrehozott digitális valóság látható.

\subsubsection{Kibertér és telejelenlét}

A telejelenlét és távmúködtetés koncepciója szorosan kapcsolódik a kibertér (Cyberspace) fogalmához. A kibertér elnevezés Willam Gibson: Neuromancer címú regényéből származik (1986), amely szerint a jövőben a világot a nagyméretű számítógépes hálózatok és adatbázisok uralják majd. A kibertér egy globális méretű mesterséges valóság, amely a számítógépes hálózaton keresztül egyszerre több ember által is megtekinthető. Egyszerűen megfogalmazva kibertér az a hely, ahová felcsatlakozunk, amikor használjuk pl. a számítógépes hálózatot, vagy ahol telefonálás közben vagyunk.

A telejelenlét kifejezés arra utal, hogy virtuálisan olyan helyen jelenünk meg, ami eltér a valós tartózkodási helyünktől. A felhasználók a legtöbb esetben térben távol helyezkednek el egymástól és a technika segítségével mégis lehetőségük van a szinkron kommunikációra.

\subsection{A virtuális valóság eszközei}

A virtuális valóság kapcsán többnyire azokra az immerzív rendszerekre gondolunk, amelyek legfontosabb jellemzője a digitális technológiával létrehozott háromdimenziós tér, és amelyben a felhasználó a VV sajátos hardver eszközeit is használja: pl. fejre erősíthető megjelenítő (sisak), a virtuális térben megvalósuló interakciót segítő eszközök, pozíciókövetés és térhatású hangrendszer. Ezek az eszközök - külön-külön - már a kilencvenes években is léteztek, de szinte kizárólag csak a katonai és tudományos kutatólaboratóriumokban használták együtt őket. Az ezredforduló után bekövetkezett informatikai fejlődés tette lehetővé, hogy mára széles körben elérhetővé váltak, ráadásul (pl. képminőség szempontjából) sokkal jobbak az ezredforduló előtti elődöknél.

\subsubsection{Számítógépre épülő VV eszközök}

A realisztikus virtuális tér előállításához és manipulálásához nagy számítási teljesítményre van szükség. Nem véletlen, hogy a legjobb képminőséget, a gyors múködést, a magasfokú immerzivitásélményt, és a viszonylag nagy területen (akár 100 négyzetméter) megvalósuló precíz pozíciókövetést tekintve máig ezek az eszközök teljesítenek a legjobban. Ráadásul a legújabb eszközök képesek a teljesen vezeték nélküli üzemmódra is (pl. HTC Vive Pro). 
A számítógépre épülő VV eszközök előnyei között meg kell említenünk, hogy az oktatási felhasználást tekintve a legjobb választásnak tekinthetjük őket. Lehetőségünk van egyrészt számos gyártó előre elkészített, rekreációs vagy oktatási célú termékéből választani, másrészt ezek az eszközök lehetőséget adnak a tanulók által fejlesztett virtuális terek illetve alkalmazások megtekintésére is. További előny, hogy a VV megjelenítésére alkalmas nagyteljesítményű számítógépek nem csak erre a célra használhatók, hanem megszokott iskolai alkalmazások mellett (pl. irodai szoftverek) más, nagy számításigényű feladatok elvégzésére is (pl. mozgóképeditálás, animációkészítés, állóképszerkesztés stb.). $A z$ is a számítógép alapú rendszerek mellett szól, hogy a gépek modulárisan fejleszthetők: ha több tárhelyre, vagy nagyobb teljesítményű videókártyára van szükség, akkor az a teljes rendszer kicserélése nélkül megoldható. A moduláris felépítés további előnye, hogy az elromlott alkatrész pótlása viszonylag egyszerüen megoldható és a számítógép ismét használhatóvá válik.

A számítógépre épülő VV eszközök hátrányai között elsőként kell említenünk a magas árat, ami a VV megjelenítőrendszeréből (sisak, navigáció stb.) és a nagyteljesítményű számítógépből tevődik össze. Ezek a költségek még akkor is nagyon magasak, ha nem egy osztálytermet, hanem pl. egy 5 munkaállomásos labort szeretnénk létrehozni. További hátrány, hogy a virtuális terek bejárásához valós térre is szükség van, sok tanteremben nehezen megoldható pl. egy 10×10 méteres terület leválasztása az osztályteremből.

A számítógépre épülő VV eszközök hátrányai között kell említenünk azt is, hogy a rendszer telepítése és karbantartása szakértelmet kíván (azonban hozzá kell tennünk, hogy a telepített és jól beállított rendszer használata nagyon egyszerű).

\subsubsection{Mobiltelefonra épülö WV eszközök}

Míg a számítógépre épülő VV eszközök a legdrágább szegmensei a VV eszközöknek, addig a mobiltelefonra épülők a legolcsóbbak. A mobiltelefonok számítási és grafikai teljesítményének növekedése tette lehetővé, hogy ezeket az eszközöket virtuális megjelenítésére használhassuk. Ehhez csak egy olyan keretre van szükségünk, amelyben elhelyezhetjük a mobiltelefonunkat, és az eszközt a szemünk elé helyezve - két lencse segítségével - máris a virtuális térben találjuk magunkat. Az eszköz egyszerűségét mutatja, hogy a Google pl. papírból készített 1-2 ezer forintért megvásárolható eszközt Google Cardboard néven. Ezen az eszközön már első ránézésre látszik, hogy nem órákon át történő használatra tervezték, de alacsony ára lehetővé teszi, hogy akár az egész osztály minden tanulója egyszerre kipróbálhassa a VV élményét.

A mobiltelefonra épülő VV eszközök legnagyobb előnye, hogy viszonylag olcsók, bár a jobb minőségű eszközök ára (2020-ban) akár a 40 000ft-ot is elérheti. További előny, hogy a legtöbb osztályban megtalálhatók azok a mobiltelefonok, amelyek alkalmasak a virtuális valósághoz köthető applikációk és videók futtatására illetve lejátszására. Ahogyan a számítógépre épülő VV eszközöknél, úgy itt is 
lehetőségünk van egyrészt számos gyártó előre elkészített, rekreációs vagy oktatási célú applikációjából választani, másrészt ezek az eszközök lehetőséget adnak a tanulók által fejlesztett virtuális terek illetve alkalmazások megtekintésére is.

A mobiltelefonra épülő $V V$ eszközök hátrányai között elsőként kell említenünk a képminőséget, a múködés sebességét és az immerzivitásélmény minőségét. A rendszer további hátránya, hogy a felhasználó pozíciójának változását (pl. mozgás előre vagy hátra) nem tudják követni, legfeljebb a fej mozdulatait. Az eszközök múködési ideje korlátozott, legfeljebb 2-3 óra még abban az esetben is, ha a telefon teljesen fel volt töltve a használat elején (a keret miatt a használat közbeni töltés rendszerint nem lehetséges).

Nagyjából 4-5 évvel ezelőtt indult a mobiltelefonra épülő VV eszközök fejlesztése és kezdetben olyan sikeresnek bizonyult, hogy a legdrágább eszközök közé tartozó Samsung Gear VR-ből is több mint ötmilliót adtak el. 2019-ben azonban a Google és Samsung is bejelentette, hogy a továbbiakban már nem gyárt és forgalmaz mobiltelefonra épülő VV eszközöket.

\subsection{3 Önálló VV eszközök}

Alig egy évvel a mobiltelefonra épülő $V V$ eszközök megjelenése után már nyilvánvalóvá vált, hogy a felhasználók egy része még rövid időre sem szívesen válik meg a mobiltelefonjától, illetve az állandó tárhely- és energiahiány miatt a mobiltelefonra épülő VV eszközök nem mindenki számára jelentenek optimális megoldást. Annak érdekében, hogy az önálló VV eszközök széles körben elérhetők legyenek, számos gyártó a mobiltelefonokra mind hardver, mind operációs rendszer (pl. Android) tekintetében kísértetiesen hasonló eszközre építette a rendszerét. Ebből adódnak az önálló VV eszközök (pl. Oculus Go) előnyei: a szoftver és hardver kiforrott technológiára épül, amelyre számos applikáció elérhető. További előny, hogy az eszköz viszonylag olcsó.

Ezeknél az eszközöknél is lehetőségünk van számos gyártó előre elkészített, rekreációs vagy oktatási célú applikációjából választani, illetve ezek az eszközök lehetőséget adnak a tanulók által fejlesztett virtuális terek és alkalmazások megtekintésére is.

Az önálló VV eszközök hátrányai között meg kell említenünk (hasonlóan a mobiltelefonra épülő VV eszközökhöz), hogy a képminőséget, a működés sebességét és az immerzivitásélmény minőségét tekintve kénytelenek vagyunk kompromisszumokat kötni.

\subsubsection{Játékkonzolra épülő W eszközök}

A virtuális valóság a kezdetektől fogva nagyon csábító volt a játékipar számára. Segítségével élethúbb, ezáltal nagyobb játékélményt nyújtó virtuális tereket és szereplőket hozhattak létre. A számítógépes játékok szerepe rendkívül jelentős a virtualitás valósághűségének fejlődésében, hiszen a részletgazdag grafika megjelenítéséhez kifinomult szoftveres megoldásokra és korszerű hardverre 
volt szükség, amiért a játékok kedvelői hajlandóak magas árat fizetni, ezzel gyorsítva a fejlődés folyamatát.

Valószínű, hogy a játékkonzolra épülő VV eszközök ötletét az adta, hogy a viszonylag nagy számítási és grafikai teljesítményű eszközök kiváló kiindulási alapot szolgáltatnak, "csupán" egy sisakot kell kifejleszteni, valamint a felhasználó pozíciókövetését megoldani és máris kész a VV rendszer. Természetesen a feladat ettől sokkal bonyolultabb volt, de a tőkeerős konzolcégek olyan fejlesztőcsapattal rendelkeznek, amelyek viszonylag rövid idő alatt meg tudták oldani a feladatot. Ráadásul a játékkonzolok nagyon népszerúek (a PS4 alapú Playstation VR konzolból 2020-ig, több mint 100 millió került eladásra ).

\subsection{A virtuális valóság és az oktatás}

Ma még a virtuális valóság legdinamikusabban fejlődő területe a szórakoztatóiparban található, de a legtöbb kutató egyetért abban, hogy a virtuális valóság forradalmasíthatja az oktatást. A Samsung által végzett kutatás szerint ${ }^{31}$, amelyben 1000 közoktatásban dolgozó pedagógus vett részt, a pedagógusok $86 \%$-ának a véleménye az, hogy ez a technológia segíthet felkelteni a gyerekek érdeklődését a tananyag iránt. 93\% szerint, ha lehetőségük lenne rá, akkor a gyerekek szívesen használnák a VV eszközöket a tanórán és $83 \%$ szerint a virtuális valóság segíthet javítani a tanulási eredményeket: fogalmak jobb megértése (a pedagógusok 77\%-a szerint), hatékonyabb együttmúködés (71\% szerint) és nagyobb motiváció (84\% szerint).

Amikor arról kérdezték a pedagógusokat, hogy szerintük mely területeken lehetne a leghatékonyabban használni a VV eszközöket, akkor 82\% említette a természettudományokat, $81 \%$ a társadalomtudományokat, illetve szintén 81\% a történelem tantárgyat.

A kutatás szerint a tanárok többsége úgy véli, hogy a virtuális valóság többféle módon is integrálható lenne az oktatási folyamatba:

A tanárok 68\%-a szerint a virtuális valóság nagyszerúen kiegészíthetné a módszertani eszköztárat, hasznos lehet pl. megnézni egy irodalmi müről készült háromdimenziós ajánlót, vagy egy kémiai reakciót.

A tanárok 72\%-a szerint a virtuális valóságra épülő szimulációk élményszerübbé tehetnék az oktatást, pl. részt venni az emberiség első repülésén a Wright fivérekkel, vagy részvényekkel kereskedni a tőzsdén.

31 https://www.businesswire.com/news/home/20160627005621/en/Survey-Finds-Teachers-Virtual-Reality-RealityClassroom 
A tanárok 69\%-a alkalmazna virtuális túrákat az olyan távoli helyek megtekintésére, mit a Stonehenge vagy a Machu Picchu, és 68\% szerint a VV ideális lenne az olyan, megközelíthetetlen helyek felfedezésére, mint a vulkánok belseje, vagy a világür.

A középiskolai tanárok 42\%-a a VV segítségével keresné fel az egyetemek kampuszait, hogy ösztönözze tanulóit a felsőoktatási intézményekbe való jelentkezésre.

Az Extreme Networks kutatása ${ }^{32}$ szerint, amelyben összesen 350 amerikai egyesült államokbeli köz- és felsőoktatási intézmény vett részt, az intézmények 23\%-a már kipróbálta a VV eszközeit az intézményben, $77 \%$ még nem.

Akik már kipróbálták, azok szerint a VV a legjobban az alábbi területeken alkalmazható:

- fizika, kémia, biológia (52\%),

- történelem (29\%),

- mérnöki tudományok (20\%),

- múvészetek (15\%),

- matematika (12\%),

- dizájn (10\%),

- irodalom és nyelvtan (angol), (9\%),

- egyéb (pl. informatika, társadalomtudományok, technológiai ismeretek stb.) (23\%).

Meglepő, hogy azok közül az intézmények közül, akik már kipróbálták a VV eszközöket az oktatásban, csupán 6\% használja rendszeresen, 19\% alkalmanként, 53\% viszont soha nem használja az oktatási folyamatban ezt a technológiát. Ez annál inkább meglepő, mert ha a kérdés a VV eszközeinek jövőbeli használatát vizsgálta, akkor a válaszadó intézmények csupán 4\%-a volt, amelyek nem tervezik a jövőbeni használatát az eszköznek (szemben az 55\%-kal akik viszont igen, és $40 \%$ bizonytalan a kérdést illetően).

Amikor az Extreme Networks kutatásában ${ }^{33}$ a tanárokat arról kérdezték, hogy szerintük melyek a VV pozitív hatásai az oktatási folyamatra nézve, az alábbi válaszok születtek:

- motiválja a tanulókat (68\%)

- fejleszti a kreativitást (39\%)

- segít megérteni a bonyolult fogalmakat (32\%)

- jelentősen csökkenti a terepgyakorlatok költségét (23\%),

- lehetővé teszi, hogy a tanulók helytől függetlenül részt vehessenek az oktatási folyamatban (15\%),

- segít kiküszöbölni az órán a zavaró tényezőket (5\%).

\footnotetext{
${ }^{32} \mathrm{http} / / /$ www.extremenetworks.com/virtual-reality-surging-classroom/ utolsó hozzáférés: 2019. 11. 05.

${ }^{33} \mathrm{http}: / /$ www.extremenetworks.com/virtual-reality-surging-classroom/ utolsó hozzáférés: 2019. 11. 05.
} 


\subsection{VV tartalmak}

Ahogyan az Extreme Networks 2016-os kutatása során a tanárok válaszaiból kiderült, a VV iskolai bevezetésének egyik hátráltatója, hogy nincs elegendő, az oktatásban használható tartalom. Szerencsére ez a helyzet évről évre változik, és úgy tűnik, hogy egyre több tartalomfejlesztő tartja fontosnak, hogy az oktatásban is használható digitális tartalmak készüljenek. Steve Bambur évek óta foglalkozik a VV oktatási integrációjával, és készített egy listát a kedvenc területeiről, amit a Dubai GESS (Global Educational Suplies \& Solutions) konferencián adott elö ${ }^{34}$ :

\subsubsection{Globális teleportálás}

Annak a lehetősége, hogy a VV segítségével szinte bárhová eljuthatunk. A Google által létrehozott Google Earth $\mathrm{VR}^{35}$ az egyik legfontosabb tartalomszolgáltató ezen a területen.

\subsubsection{Időutazás}

A VV tanórai integrációját segíti (pl. történelemből), hogy a tanulóknak a technológia segítségével lehetőségük van arra, hogy a tankönyv ábrái helyett sétát tegyek az ókori Róma terein a Rome VR segítségével ${ }^{36}$.

\subsubsection{Multiszenzuális élmények}

A Sky VR által fejlesztett Hold the World alkalmazásban a tanulók a Londoni Természettudományi Múzeum 3D fosszíliáit interaktív módon, David Attenborough audiokommentárjával tekinthetik $\mathrm{meg}^{37}$.

\subsubsection{Különleges képességek}

A Google Tilt Brush segítségével a tanulók kreativitásukat és művészi ambícióikat - részben a fizika törvényeinek meghazudtolásával - valósíthatják meg ${ }^{38}$.

\subsection{5 Önálló felfedezés}

Az önálló felfedezés lehetősége az jelenti, hogy a tanulóknak lehetőségük van a saját tempójukban és érdeklődési preferenciáiknak megfelelően navigálni a virtuális térben, legyen szó a Titanicról ${ }^{39}$ vagy a Marsról ${ }^{40}$.

\footnotetext{
${ }^{34}$ https://www.vrfocus.com/2019/03/10-key-benefits-of-vr-in-education/

${ }^{35}$ https://arvr.google.com/earth/

${ }^{36} \mathrm{https}: / /$ unimersiv.com/ancient-rome-virtual-reality/

${ }^{37}$ https://www.factory42.uk/holdtheworld

${ }^{38}$ https://www.tiltbrush.com

${ }^{39} \mathrm{https} / / /$ immersivevreducation.com/products-vr-experiences/titanic-vr/

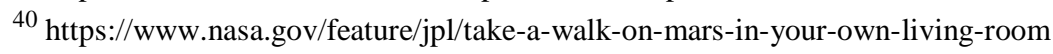




\subsubsection{Virtuális próba}

Nem könnyű egy nézőkkel teli teremben kiállni a színpadra és beszédet tartani, ráadásul ezeket a készégeket kifejezetten nehéz fejleszteni. Ebben segíthet a Virtual Speech alkalmazás ${ }^{41}$, amely segítségével a tanulók gyakorolhatják többek között a nyilvános beszédhez és a prezentáció tartásához kapcsolódó helyzeteket.

Videó a Google Tilt Brush használatáról: https://youtu.be/TckqNdrdbgk

Amikor az Extreme Networks kutatásában ${ }^{42}$ a tanárokat arról kérdezték, hogy milyen VV tartalmakat használnak az órán, az alábbi válaszok születtek:

- Google (35\%),

- YouTube (24\%),

- Oculus (15\%),

- $\quad$ Nearpod (7\%),

- nyílt oktatási erőforrások (4\%),

- Netflix (3\%),

- Samsung (2\%),

- egyéb (8\%).

\subsubsection{Telejelenlét}

A VV típusainál már röviden bemutatásra került a telejelenlét és Steve Bambur is említi a Dubai GESS (Global Educational Suplies \& Solutions) konferencián, mint az oktatásban jól használható területét a VV-nek. A telejelenlét kifejezés arra utal, hogy virtuálisan olyan helyen jelenünk meg, ami eltér a valós tartózkodási helyünktől. A felhasználók a legtöbb esetben térben távol helyezkednek el egymástól és a technika segítségével mégis lehetőségük van a szinkron kommunikációra. Sajnos a rendelkezésre álló technológia még ma sem teszi lehetővé, hogy teljes testünket 3D szkennerrel beszkenneljük, és a fizikai valónk élethű mása valós időben jelenjen meg a virtuális térben (különösen igaz ez pl. az arckifejezésekre), ehelyett egy virtuális helyettesítő karaktert, avatárt kell használnunk.

\subsubsection{Az avatár}

A virtuális terekben kezdetben a felhasználó egyáltalán nem jelenhetett meg, mert a technika nem volt alkalmas erre a feladatra. Később a technológiai fejlődés lehetővé tette, hogy a felhasználó egyes testrészeinek (pl. kéz) stilizált vagy valós képe és a virtuális tér elemei együtt jelenjenek meg.

\footnotetext{
${ }^{41}$ https://play.google.com/store/apps/details?id=com.virtualSpeech.android\&hl=hu

$42 \mathrm{http}: / /$ www.extremenetworks.com/virtual-reality-surging-classroom/ utolsó hozzáférés: 2019. 11. 05.
} 
Később az is lehetővé vált, hogy a szereplők arca is szinte fotorealisztikus pontossággal kerüljön bele a virtuális térbe.

Az avatár kifejezés a külsőnk virtuális megjelenési formáját jelenti, amelyet a virtuális terekben használunk. Amikor belépünk a virtuális térbe (elindítunk egy programot, kapcsolódunk egy webes szolgáltatáshoz), az általunk kreált karakter fog képviselni minket, ez fog megjelenni a képernyőn és ezt a karaktert fogja látni a virtuális közösség többi résztvevője is.

$A z$ avatárunk létrehozásakor általában kiválaszthatjuk összes külső megjelenési jellemzőnket, kezdve a nemünktől a hajunk, szemünk színéig stb. A különböző virtuális terek és közösségek különböző mértékben testreszabható avatárokat kínálnak fel, sőt akár vásárolhatunk is előre elkészített karaktereket.

\subsection{A Second Life}

Az SL-nek rövidített közösséget az 1999-ben alapított Linden Lab hozta létre 2003-ban, hogy teljesen új formáját alkossa meg az online virtuális közösségi tereknek.

A virtuális tereket nagyrészt a közösség tagjai hozzák létre, a regisztrációk száma elérte a hatvanmilliót, de az aktív felhasználók is több mint 800.000-en vannak.

A virtuális tér a http://secondlife.com weboldalon keresztül érhető el, ahol néhány perc alatt a közösség tagjaivá válhatunk, csupán regisztrálnunk kell kiválasztanunk és személyre szabnunk az avatárunkat, majd letölteni a segédprogramot, ami elengedhetetlen a 3D környezet megjelenítéséhez.

\subsubsection{A Second Life oktatási alkalmazása}

A Second Life külön oktatási platformmal rendelkezik, amelyet elsősorban a felsőoktatási intézmények számára terveztek. A Second Life oldalán jelenleg számos egyetemnek van saját virtuális intézménye, közöttük olyan híres egyetemnek is, mint pl. a Stanford University.

A Second Life oktatási platformja a nap 24 órájában elérhető, ami nagyszerű lehetőséget biztosít arra, hogy a hallgatók közösen dolgozzanak projektjeiken, illetve, ha szükségesnek látják, akkor egyedül is visszatérhetnek a virtuális tanulási környezetükbe. Különösen hasznos ez a lehetőség akkor, ha a hallgatók, munkájuk vagy az időeltolódás miatt, nem tudnak rendszeresen ugyanabban az időben együtt dolgozni a kiadott feladatokon. A tapasztalatok szerint a Second Life infrastruktúráját nemcsak azok az oktatók és hallgatók használják szívesen, akik egymástól földrajzilag távol helyezkednek el, hanem azok is, akik egy osztályteremben tartózkodnak.

\subsubsection{A Second Life népszerüségének okai}

A virtuális jelenlét során az oktatóknak és a hallgatóknak lehetőségük van online prezentációk és szimulációk megtekintésére is. A Second Life alkotói szerint éppen ez a nehezen megfogalmazható 
érzés, a virtuális jelenlét az, ami hatékonnyá teszi az oktatási alkalmazását ennek a virtuális környezetnek. Az oldal üzemeltetői szerint a siker másik kulcsa az, hogy az online képzések akkor lehetnek hatékonyak, ha el tudják érni, hogy a hallgatók rendszeresen leüljenek a számítógép elé, belépjenek az oktatási platform felületére és aktívan részt vegyenek az oktatási folyamatban. A Second Life vonzó közösségi terei pedig ennek a megvalósításában segíthetik a felsőoktatási intézményeket. Például az aktivizálásra számos apró trükköt alkalmaznak az oldal programozói: ha a hallgató a virtuális órán huzamosabb ideig nem mozdítja meg az egerét, vagy nem használja a billentyúzetet, az avatárja elalszik a virtuális térben, így az óra résztvevői látni fogják, hogy nem figyel.

\subsubsection{Oktatás a Second Lifeban}

A Second Life virtuális környezetében megvalósított képzések rendkívül színesek, de a leggyakrabban alkalmazottak az alábbiak:

- a távoktatási kurzusok,

- online prezentációk és megbeszélések,

- szerepjátékok,

- valósághű virtuális történelmi környezetben történő oktatás,

- szimulációk,

- multimédia- és számítógépes játékfejlesztés,

- idegennyelv oktatása.

A legnépszerübb képzési forma a Second Lifeban kétségtelenül az, amikor a tananyag a valóság pontos leképezésének eredményeképpen tárul a hallgatók szeme elé. Az egyik leggyakrabban említett példa a Second Life hatékonyságára, amikor azt a kérdést feszegetik, hogy mi a jobb, olvasni a Sixtusi kápolnáról vagy a virtuális térben közösen felrepülni a mennyezethez és megcsodálni a freskókat?

A Second Life volt az első olyan 3D virtuális tér, amelynek volt önálló oktatási platformja. Az ötlet kiváló volt, de sajnos már a kezdetektől fogva megjelentek olyan problémák, amelyek a felhasználói élményt csökkentették: a rendszer időnkénti leállása, a nagy erőforrásigény, a létrehozott virtuális javak "eltűnése" stb. Érdekes volt azt is megfigyelni, ahogy az avatárok arca egyre jobban közelített a fotorealisztikushoz, a virtuális személyek tekintete élettelen maradt, ami nagyon zavaró hatást keltett. Ráadásul a Second Life felületét a kezdetektől fogva képernyőn való megtekintésre szánták, ami elmarad a mai VV rendszerek immerzivitásélményétől. 


\subsection{Az Engage}

Az Engage-t az Immersive VR Education Ltd. hozta létre 2016-ban. Az Engage részben ingyenesen használható oktatási és prezentációs platform, amely célja, hogy megváltoztassa az oktatást és a kreatív ötletek megosztásának módját.

Az Engage rendszer használatához létre kell hoznunk egy felhasználói fiókot a https://engagevr.io/ weboldalon és le kell töltenünk az Engage használatához szükséges szoftvert.

Az Engage lehetővé teszi a felhasználók számára, hogy egy olyan virtuális teremben találkozzanak, amely messzemenően támogatja nem csak a VV technológia legújabb vívmányait, de az olyan hagyományos szemléltető eszközöket is, mint a fehértábla, és a felhasználók természetesen bármilyen típusú fájlt és médiumot megoszthatnak egymással.

Az Engage rendszert egyszerre akár 30 felhasználó is igénybe veheti, de arra is lehetőség van, hogy egyetlen felhasználó (pl. az oktató), minden tevékenysége (prezentáció, mozgás a virtuális térben stb.) rögzítésre és a hallgatókkal megosztásra kerüljön.

Az Engage támogatja a legelterjedtebb VV eszközöket, pl. HTC Vive, Oculus Rift stb. de természetesen lehetőség van arra is, hogy a számítógép monitorán vagy egy Android operációs rendszert futtató tablet vagy okostelefon képernyőjén keresztül szemléljük az Engage virtuális világát.

\subsection{A VV veszélyei}

Amikor az Extreme Networks kutatásában ${ }^{43}$ a tanárokat arról kérdezték, hogy szerintük mely érvek szólhatnak a VV iskolai bevezetése ellen, akkor a tanárok 16\%-a azt mondta, hogy nem tud ilyen érvet megemlíteni, a többiek válaszai a következők:

- jelenleg még nincs elegendő, az oktatásban felhasználható tartalom (47\%),

- drága, és bonyolult a telepítése (43\%),

- nehéz az órai munka menetébe beilleszteni (21\%),

- megzavarhatja az órát (22\%),

- fejfájást, esetleg agykárosodást okozhat (17\%),

- túlságosan játékszerű (16\%),

- elszigetelheti a tanulókat (8\%).

\footnotetext{
${ }^{43} \mathrm{http} / / /$ www.extremenetworks.com/virtual-reality-surging-classroom/ utolsó hozzáférés: 2019. 11. 05.
} 


\subsubsection{Szorongás}

A virtuális és a kibővített valóság immerzivitása és magával ragadó jellege a felhasználóban akár néhány perc után is a stressz vagy a szorongás érzését okozhatja. Különösen igaz ez abban az esetben, ha felkavaró jelenetek (pl. háború) zajlanak a felhasználó szeme előtt.

\subsection{2 Émelygés és hányinger}

Egyesek, akik VR fejhallgatót használnak, szédülésre és hányingerre panaszkodnak. Reális szimulált mozgásai befolyásolhatják az ember idő és tér érzékelését, és fáradtságot, émelygést szédülést vagy ájulást, a gyors villogást tartalmazó jelentek pedig epilepsziás rohamokat okozhatnak.

\subsubsection{A szem}

A VV szemüvegek, sisakok jelentős mértékben megterhelik a szemet, mert a használat során ugyanarra a viszonylag kis távolságra kell fókuszálnia a szemnek, függetlenül a megfigyelt virtuális tárgy látszólagos távolságától. Azok a kutatók, akik a mesterséges eszközökkel létrehozott sztereoszkópikus látás hatásait vizsgálják, azt állítják, hogy az emberi szem károsodik a hosszantartó mesterségesen előállított háromdimenziós terek látványától, és különösen oda kell figyelni a gyermekek ilyen irányú tevékenységeire, mivel a Leeds Egyetem ${ }^{44}$ által végzett vizsgálat szerint már 20 perc eltöltése a VV-ban befolyásolhatja a szem akkomodációját.

\subsubsection{Sugárzás}

Az olyan viselhető technológiák, mint a VR szemüveg vagy sisak, potenciálisan káros elektromágneses hullámoknak (pl. WiFi, Bluetooth) teszik ki a felhasználót. Különösképpen igaz ez azokra az eszközökre (Samsung Gear VR, Google Daydream View stb.), amelyekben egy mobiltelefont kell elhelyezni. Az elektromágneses sugárterhelés akkor a legintenzívebb, anikor a telefonok a szolgáltató adótornyaival kommunikálnak (a kommunikáció rendszeres, még akkor is, ha a felhasználó nem kezdeményez és nem fogad hívást). Az elektromágneses hullámok negatív hatását (alvászavar, rákos megbetegedések ${ }^{45}$ stb. tovább növeli, hogy a mobiltelefon a használat során nagyon közel van a felhasználó fejéhez.

\subsubsection{Szimulátorbetegség}

A szimulátorbetegség akkor jelentkezhet, ha a mozgás látványa és a mozgás érzékelése nincs összhangban egymással, pl. a szemünk által küldött információ szerint a virtuális térben futunk, de a

\footnotetext{
44 https://medium.com/university-of-leeds/is-virtual-reality-bad-for-our-health-the-risks-and-opportunities-of-a-technologyrevolution-31520e50820a

45 https://www.who.int/en/news-room/fact-sheets/detail/electromagnetic-fields-and-public-health-mobile-phones
} 
többi szervünk (egyensúlyszerv, izmok stb.) ezzel ellentétes információt továbbít az agyunk felé. A szimulátorbetegség mértéke egyéni érzékenység szerint változó lehet, de rendszerint annál intenzívebb, minél nagyobb arányban kerül lefedésre az adott érzékszervi csatorna, pl. látómező (a monitornál ez az érték kisebb, a VV szemüvegnél nagyobb) illetve lehetőleg kerülni kell bizonyos különleges hatásokat (pl. alacsony magasságban hátrafelé repülni).

\section{A 3D nyomtatás}

A 3D nyomtatás során 3D tárgyat állítunk elő egy digitális fájlból (vagy fájlokból). Az eljárás az additív gyártástechnológiára épül, a latin eredetű additív szó jelentése: hozzáadó, összegző, ami itt arra utal, hogy a 3D tárgyat nagyon vékony rétegekből, rétegről rétegre haladva állítjuk elő. Talán könynyebb megérteni a 3D nyomtatás lényegét, ha felidézzük az óvodai gyurmázáshoz köthető emlékeinket: szinte mindannyian készítettünk kis méretű poharakat vagy vázákat gyurmahurkákból. Először elkészítettük a váza alját, majd a gyurmahurkákat ráillesztettük az alapra, pontosan követve annak körvonalát. A legtöbb, az iskolákban használt 3D nyomtató, ehhez nagyon hasonló elven múködik: egy nyomtatófejből nagyon vékony $(\mathrm{kb} .0,1 \mathrm{~mm})$, olvadt műanyagszálat helyezünk szorosan egymás mellé illetve egymásra, így létrehozva a 3D tárgyat. Az eljárást Fused Deposition Modeling-nek, vagy röviden FDM-nek nevezzük.

\subsection{A 3D nyomtatás anyagai}

Ma már számos 3D nyomtatási technológia elérhető és mindegyik más-más nyersanyagot használ a nyomtatáshoz. Ha az iskolai nyomtatásra koncentrálunk, akkor a két leggyakrabban használt anyag a PLA és az ABS. A nyomtatáshoz szükséges nyersanyagot töltőanyagnak, vagy filamentnek szokták nevezni.

\subsubsection{A PLA}

A PLA (polylactic acid), vagy más néven politejsav, egy hőre lágyuló múanyag, bár sokan tiltakoznak a műanyag elnevezés ellen, hiszen többé-kevésbé természetes alapú anyagról van szó. A PLA-t kukoricából, cukornádból stb. állítják elő és a közösségi hálózatokon olyan információt is olvashatunk róla, hogy annyira környezetbarát, hogy a földbe elásva néhány hónap alatt teljesen elbomlik. Ez sajnos nem igaz, a PLA-t csak ipari komposztálókban lehet lebontani, megfelelő körülmények között (legalább 60 Celsius fok, megfelelő PH-értékű és páratartalmú közeg stb.). Sajnos a magas páratartalom a kinyomtatott tárgyak mechanikai tartósságát jelentősen befolyásolja (negatív irányban), ezt érdemes figyelembe venni a tárgyak és a töltőanyag tárolásánál. 
A másik jellemző, amit a PLA-val kapcsolatban meg szoktak említeni, hogy ideális az osztálytermek zárt terében való használatra, mert nincs semmilyen szaga. Ez csak abban az esetben igaz, ha csak nagyon rövid ideig múködtetjük a nyomtatót. Nagyobb tárgyak vagy hosszú ideig tartó nyomtatás közben édeskés illat tölti meg a termet, amit nem mindenki szeret, ezért ilyenkor érdemes gondoskodni a helyiség szellőztetéséről. Mindig a nyomtatónak megfelelő és ellenőrizhető gyártó által előállított töltőanyagot vásároljunk: ezzel egyrészt óvjuk a nyomtatónkat, másrészt biztosak lehetünk benne, hogy a töltőanyag melegítésekor nem keletkeznek olyan anyagok, amelyek belélegezve károsak lehetnek az egészségre.

A PLA-t számos színben be lehet szerezni, léteznek különleges, áttetsző, fluoreszkáló és különféle adalékanyagot (pl. gipsz) tartalmazó töltőanyagok, amelyek nagyon változatos felhasználást tesznek lehetővé.

\subsubsection{ABS}

Az ABS (Acrylonitrile Butadiene Styrene vagy magyarosabban akrilnitril-butadién-sztirol). Az ABS jól bírja az igénybevételt, rugalmasabb, nem törik olyan könnyen mint a PLA és könnyen megmunkálható. A nyomtatott felület simává tehető, ha acetonnal kezeljük, illetve az aceton a munkadarabok összeragasztására is alkalmas. Számos helyen találkozhatunk vele (pl. műszaki cikkek borítása), de a legismertebb felhasználási területe a LEGO kocka. 3D nyomtatása csak magasabb hőmérsékleten valósítható meg (a PLA-hoz viszonyítva), és nyomtatás közben jellegzetes szag érezhető, emiatt zárt osztálytermekben nem javasolt a használata.

\subsection{Fájlok 3D nyomtatáshoz}

Ahogyan már volt szó róla, a 3D nyomtatás során 3D tárgyat állítunk elő egy fájlból, ilyen fájl pl. az .stl (stereolitography), amit számos CAD (Computer Aided Design) szoftver is használ. Tehát ahhoz, hogy egy tárgyat ki tudjunk nyomtatni a 3D nyomtatónkkal, rendelkeznünk kell egy .stl fájllal. Háromféle módon is szert tehetünk egy ilyen fájlra:

- letölthetünk korábban már létrehozott fájlt (pl. a thingiverse.com oldalról),

- 3D tervezőprogrammal elóállíthatjuk (pl. AutoCad szoftver, vagy tinkercad.com weboldal)

- 3D szkenneléssel (pl. a 3D Creator mobil applikáció segítségével)

Amikor letöltöttük, megalkottuk, vagy szkenneléssel létrehoztuk a 3D objektumot, a nyomtatás előtt szükségünk lehet egy olyan szoftverre, ami előkészíti a nyomtatást: létrehozza és átküldi a nyomtatónak azt a több száz vagy több ezer vékony szeletet, amelyből a 3D objektum felépül. Szerencsére számos esetben ( $p l$. a tinkercad.com weboldalon vagy az Ultimaker Cura szoftverben) ez a funkció integrálásra kerül. 


\subsection{A 3D nyomtatás szerepe az oktatásban}

A 3D nyomtatás segítheti a kíváncsiság felkeltését, a kreativitás kibontakoztatását és a kritikus gondolkodást. A 3D nyomtatás kiválóan integrálható a projektszemléletű oktatásba, az eljárás közvetlen módon támogatja a problémafelvetésnek, a lehetséges megoldások keresésének, az optimálisnak tűnő megoldás kiválasztásának, a megoldás megvalósításának és értékelésének folyamatát. A 3D nyomtatás további előnye, hogy a választott megoldás helyessége azonnal ellenőrizhető és az esetleges kudarc a feladat újragondolására és új, jobb megoldások keresésére ösztönöz (ellentétben a pl. a szummatív értékeléssel záródó dolgozatokkal), a tanuló kezébe adva ezzel a tanulási folyamat felletti irányítás egy részét. A 3D nyomtatási feladatokhoz kapcsolódó szemlélet és módszer ezáltal segíthet felkészíteni a tanulókat arra, hogy felnőtt korukban megfeleljenek a 21. századi munkavállalókkal szemben támasztott követelményeknek és elvárásoknak.

\section{Összegzés}

A 21. század oktatásában nagyon fontos szerepet játszanak a digitális eszközök, amelyek képesek megragadni és fenntartani a tanulók érdeklődését. A digitális taneszközök közül is kiemelkednek a digitális 3D eszközök, amelyek vizuálisan vonzó formában jeleníthetik meg az oktatási tartalmakat. Az előző néhány oldalon a virtuális valóság és a 3D nyomtatás néhány jellemzője került bemutatásra.

A virtuális valóság alkalmazása az oktatás szinte minden területén ígéretesnek tűnik, azonban az eszközök magas ára, a tantervhez szorosan illeszkedő digitális oktatóanyag hiánya és a virtualitáshoz kapcsolódó lehetséges negatív hatások veszélye egyelőre útját állja a technológia széleskörű elterjedésének.

Az eddigi tapasztalatok alapján úgy túnik, hogy a 3D nyomtatás segítheti a tanulókban a kíváncsiság felkeltését, a kreativitás kibontakoztatását és a kritikus gondolkodás kialakulását. A 3D nyomtatás kiválóan integrálható a projekt szemléletű oktatásba és az esetleges kudarc a feladat újragondolására, új, jobb megoldások keresésére ösztönözheti a tanulókat.

Széleskörű elterjedésük után a bemutatott digitális 3D eszközök - megfelelő módszertannal párosítva - élményszerúbbé tehetik az ismeretátadást és segíthetnek felkészíteni a tanulókat arra, hogy felnőtt korukban megfeleljenek a 21. századi munkavállalókkal szemben támasztott követelményeknek és elvárásoknak. 


\section{Irodalomjegyzék}

Bamford, A. (2011). The 3D in education white paper, Technical report, International Research Agency.

McLellan, H (1997). Virtual Realities, in Handbook of Research for Educational Communications and Technology

Jonassen,D., DriscollM., (szerk.) (2004). Handbook of Research on Educational Communications and Technology, Routledge, New York

Sherman, W. R., Craig, A. B. (2002). Understanding Virtual Reality: Interface, Application, and Design, Morgan Kaufmann, San Francisco, CA.

Shibata, T. (2014). Utilization of stereoscopic 3D images for social studies class in elementary school, EdMedia, pp.2575-2580.

Shibata, T., Sato, K., \& Ikejiri, R. (2017). Generating questions for inquiry-based learning of history in elementary schools by using Stereoscopic 3D images

https://doi.org/10.1587/transele.E100.C.1012 